\title{
GMR
}

\section{Selecting elephant grass families and progenies to produce bioenergy through mixed models (REML/BLUP)}

\author{
E.V. Rodrigues ${ }^{1}$, R.F. Daher ${ }^{2}$, A. dos Santos $^{3}$, M. Vivas ${ }^{2}$, J.C. Machado ${ }^{4}$, \\ G. do A. Gravina' ${ }^{2}$, Y.P. de Souza ${ }^{2}$, A.K. Vidal' ${ }^{2}$ A. dos S. Rocha ${ }^{2}$ and \\ R.S. Freitas ${ }^{2}$ \\ ${ }^{1}$ Embrapa Agroenergia, Parque Estação Biológica, Brasília, DF, Brasil \\ ${ }^{2}$ Laboratório de Engenharia Agrícola, \\ Centro de Ciências e Tecnologias Agropecuárias, \\ Universidade Estadual do Norte Fluminense Darcy Ribeiro, \\ Campos dos Goytacazes, RJ, Brasil \\ ${ }^{3}$ Laboratório de Melhoramento Genético Vegetal, \\ Centro de Ciências e Tecnologias Agropecuárias, \\ Universidade Estadual do Norte Fluminense Darcy Ribeiro, \\ Campos dos Goytacazes, RJ, Brasil \\ ${ }^{4}$ Empresa Brasileira de Pesquisa Agropecuária, \\ Embrapa Gado de Leite, Juiz de Fora, MG, Brasil \\ Corresponding author: E.V. Rodrigues \\ E-mail: erina.rodrigues@colaborador.embrapa.br
}

Genet. Mol. Res. 16 (2): gmr16029301

Received September 19, 2016

Accepted April 11, 2017

Published May 18, 2017

DOI http://dx.doi.org/10.4238/gmr16029301

Copyright $(2017$ The Authors. This is an open-access article distributed under the terms of the Creative Commons Attribution ShareAlike (CC BY-SA) 4.0 License.

ABSTRACT. Brazil has great potential to produce bioenergy since it is located in a tropical region that receives high incidence of solar energy and presents favorable climatic conditions for such purpose. However, the use of bioenergy in the country is below its productivity potential. The aim of the current study was to select full-sib progenies and families of elephant grass (Pennisetum purpureum S.) to optimize phenotypes relevant to bioenergy production through mixed models

Genetics and Molecular Research 16 (2): gmr16029301 
(REML/BLUP). The circulating diallel-based crossing of ten elephant grass genotypes was performed. An experimental design using the randomized block methodology, with three repetitions, was set to assess both the hybrids and the parents. Each plot comprised 14-m rows, $1.40 \mathrm{~m}$ spacing between rows, and $1.40 \mathrm{~m}$ spacing between plants. The number of tillers, plant height, culm diameter, fresh biomass production, dry biomass rate, and the dry biomass production were assessed. Genetic-statistical analyses were performed through mixed models (REML/BLUP). The genetic variance in the assessed families was explained through additive genetic effects and dominance genetic effects; the dominance variance was prevalent. Families such as Capim Cana D'África x Guaçu/I.Z.2, Cameroon x Cuba-115, CPAC x Cuba115, Cameroon x Guaçu/I.Z.2, and IAC-Campinas x CPAC showed the highest dry biomass production. The family derived from the crossing between Cana D'África and Guaçu/I.Z.2 showed the largest number of potential individuals for traits such as plant height, culm diameter, fresh biomass production, dry biomass production, and dry biomass rate. The individual 5 in the family Cana D'África x Guaçu/I.Z.2, planted in blocks 1 and 2, showed the highest dry biomass production.

Key words: Pennisetum purpureum S.; Biomass production; Plant breeding

\section{INTRODUCTION}

The global energy matrix is marked by the high prevalence of non-renewable sources. However, the growing demand for fossil fuels has increased the awareness about a possible energy crisis, since these fuels come from limited sources (Ong et al., 2013). Besides, the debates about issues related to the negative environmental impact caused by high gas emission rates, which worsen the greenhouse effect, have intensified. Therefore, it is essential to develop alternative energy sources to decrease the use of fossil fuels.

Some plants have shown potential to be used as sources of bioenergy, namely: elephant grass (Daher et al., 2014; Rocha et al., 2015; Salazar-Zeledón et al., 2015; Ghosh, 2016; Menezes et al., 2016), sugarcane (Szczerbowski et al., 2014; Bordonal et al., 2015), sorghum (Silva et al., 2016), and eucalyptus (Eufrade Junior et al., 2016). However, in contrast to elephant grass, which shows high photosynthetic efficiency with high biomass productivity potential, some of these cultures show low dry biomass production. Furthermore, the elephant grass culture shows shorter production cycle (two cuts may be performed per year), renewable energy, and increased carbon assimilation (Mazzarella et al., 2015).

Given the great energy potential of the elephant grass, it is essential to use accurate genotype-selection methods in its breeding, since plant-breeding success depends on the use of efficient genetic and experimental designs, as well as on the subsequent use of selection procedures able to explore all the favorable attributes of such designs. Unbalanced experiments are commonly used to assess elephant grass, as well as other perennial plants. In such cases, the use of traditional analysis, such as analysis of variance (ANOVA), leads to biased estimates of variance components (Resende, 2007). Thus, the best procedure to overcome such obstacle

Genetics and Molecular Research 16 (2): gmr16029301 
is the estimation of variance components through restricted maximum likelihood (REML), as well as the prediction of genetic values through the best linear unbiased prediction (BLUP).

The main advantages of applying the REML/BLUP method to simultaneously estimate genetic parameters and to predict the genetic values are: the correction of data on environmental effects, the estimation of genetic parameters and prediction of genetic values, the comparison of individuals in time and space, the generation of non-addicted results, the maximization of selective accuracy, the maximization of genetic gain and of plant-breeding programs efficiency, the non-requirement of data matching, the simultaneous use of a large number of information to generate more accurate estimates, the management of complex experimental structures and of heterogeneous variances (Resende, 2002; Viana and Resende, 2014).

The REML/BLUP method has been successfully applied to several perennial species such as Brachiaria humidicola (Figueiredo et al., 2012), Panicum maximum (Braz et al., 2013), Saccharum officinarum (Oliveira et al., 2008; Pedrozo et al., 2009; Lucius et al., 2014); Eucalyptus (Rosado et al., 2012; Miranda et al., 2015); and Coffea arabica (Rodrigues et al., 2013; Carias et al., 2016). However, there are few studies in the literature concerning the use of this method in elephant grass, so far. Such use emerges as an innovative breeding proposal in this culture since it enables the successful selection of potential clones.

The information obtained through the REML/BLUP method allows directing the selection strategies. Both the family and the individual selections stand out among all possible alternatives. However, studies have shown that the family selection is significantly advantageous (Oliveira et al., 2008), since this type of assessment comprises the selection of superior families and leads to greater probability of identifying promising genotypes within the family (Cruz et al., 2012). In light of the preceding, the aim of the current study was to select full-sib families and progenies of elephant grass to produce bioenergy through mixed models (REML/BLUP).

\section{MATERIAL AND METHODS}

The experiment was conducted in the experimental field of the State Center for Research in Agro-Energy and Waste Utilization (PESAGRO - Centro Estadual de Pesquisas em Agroenergia e Aproveitamento de Resíduos - Rio), which is located in Campos dos

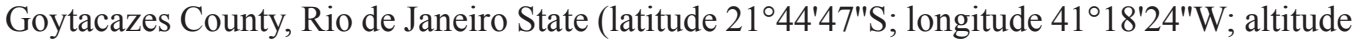
$11 \mathrm{~m})$. According to the Köppen (1948)'s classification system, the climate in the Northern Fluminense region is Aw - tropical hot and humid - and it presents dry winter and rainy summer, as well as annual rainfall of approximately $1053 \mathrm{~mm}$ (Mendonça et al., 2007). The soil in the experimental field is classified as dystrophic argisol.

Controlled crossings between ten elephant grass genotypes (Cubano Pinda, Vrukwona, IAC-Campinas, Capim Cana D’África, Cameroon, CPAC, IJ 7139, União, Guaçu/I.Z.2, and Cuba-115), which were previously selected based on studies about biomass production potential, were performed under circulating diallel system. The algorithm used to set the circulating diallel-based crossings was based on the following values (Kempthorne and Curnow, 1961): $\mathrm{p}$ number of studied parents $(\mathrm{p}=10)$; $\mathrm{s}$ - number of hybrid combinations for each parent, $\mathrm{s}<\mathrm{p}-1$ and $\mathrm{s} \geq 3$ for diallels including just $\mathrm{F} 1$ 's, and $\mathrm{s} \geq 2$, when the parents $(\mathrm{s}=3)$ are also included; $\mathrm{n}$ $=\mathrm{ps} / 2$ : total number of crossings $(\mathrm{N}=15)$; and $(\mathrm{p}+1-\mathrm{s}) / 2$ : integer $(\mathrm{k}=4)$.

The obtained seeds were sown in 128-cell Styrofoam trays filled with forest substrate. The seedlings were transplanted to the field in December 2014; 47 days after seedling

Genetics and Molecular Research 16 (2): gmr16029301 
emergence. A randomized block design, with three repetitions, was used to assess both the hybrids and the parents (Table 1). Each plot consisted of 14-m rows with $1.40 \mathrm{~m}$ spacing between rows and $1.40 \mathrm{~m}$ spacing between plants. Two assessment cuts were set: the first cut was held on July 14, 2015 (266 days after sowing), whereas the second one was held on February 19, 2016. There was a 220-day interval between the first and second assessment cuts.

\begin{tabular}{|c|c|}
\hline Field No. & Genotypes \\
\hline 1 & Cubano Pinda \\
\hline 2 & Vrukwona \\
\hline 3 & IAC-Campinas \\
\hline 4 & Capim Cana D'África \\
\hline 5 & Cameroon \\
\hline 6 & CPAC \\
\hline 7 & IJ 7139 \\
\hline 8 & União \\
\hline 9 & Guaçu/I.Z.2 \\
\hline 10 & Cuba-115 \\
\hline 11 & Cubano Pinda x Cameroon \\
\hline 12 & Cubano Pinda x CPAC \\
\hline 13 & Cubano Pinda x IJ 7139 \\
\hline 14 & Vrukwona x CPAC \\
\hline 15 & Vrukwona x IJ 7139 \\
\hline 16 & Vrukwona x União \\
\hline 17 & IAC-Campinas x IJ 7139 \\
\hline 18 & IAC-Campinas x União \\
\hline 19 & IAC-Campinas x Guaçu/I.Z.2 \\
\hline 20 & Capim Cana D’África x União \\
\hline 21 & Capim Cana D'África x Guaçu/I.Z.2 \\
\hline 22 & Capim Cana D'África x Cuba-115 \\
\hline 23 & Cameroon x Guaçu/I.Z.2 \\
\hline 24 & Cameroon x Cuba-115 \\
\hline 25 & CPAC x Cuba-115 \\
\hline
\end{tabular}

The assessed traits were: i) number of tillers (NT) - the number of tillers in each plant in the plot was counted; ii) plant height $(\mathrm{PH}, \mathrm{m})$ - measured from the base of the tiller to the leaf inflection point; iii) culm diameter $(\mathrm{CD}, \mathrm{mm})$ - measured by digital caliper, approximately $50 \mathrm{~cm}$ from the ground, in each plant of the plot; iv) fresh biomass production (FBIOM, $\mathrm{kg} /$ plant) - measured by weighing the fresh biomass collected from each plant in the plot; v) dry biomass rate (DBR, \%) - obtained by weighing a green sample (fresh weight), which was oven-dried at $65^{\circ} \mathrm{C}$ for $72 \mathrm{~h}$ and, subsequently, weighed again (dry weight), the DBR was measured by the ratio between the dry and fresh weights; and vi) dry biomass production (DBIOM, kg/plant) - measured by multiplying the fresh biomass by the dry biomass rate.

The genetic-statistical analyses were performed through mixed models (REML/ BLUP). The REML allowed estimating the genetic parameters, whereas the BLUP allowed predicting the genotypic and additive genetic values.

The current study adopted a statistical model in combination with the assessment of individuals from full-sib progenies obtained through factorial or intrapopulation diallel crossings - several plants per plot (Model 33) - using the Selegen REML/BLUP software. The following mixed model (Resende, 2007) was taken into consideration: $\mathrm{y}=\mathrm{Xr}+\mathrm{Za}+\mathrm{Wp}+\mathrm{Tf}$ $+\mathrm{e}$, where $y$ is the data vector; $r$ is the vector of repetition effects (fixed) added to the overall mean; $a$ is the vector of individual additive genetic effects (random); $p$ is the vector of plot 
effects (random), $f$ is the vector of full-sib family dominance effects (random); and $e$ is the vector of errors or residues (random). The capital letters $\mathrm{X}, \mathrm{Z}, \mathrm{W}$, and T represent the incidence matrices of the effects mentioned above.

The likelihood ratio test (LRT) was used, and the significance was assessed through the chi-square test, with one degree of freedom. The full and the reduced models were set by considering and disregarding the effect to be tested, to perform the LRT. Then, the values corresponding to -2 times the $\log$-likelihood $(D=-2 \log L)$ were subtracted.

The distributions and structures of the means (E) and variances (Var) are given through:

$$
\begin{gathered}
E\left[\begin{array}{l}
y \\
a \\
d \\
c \\
e
\end{array}\right]=\left[\begin{array}{l}
X b \\
0 \\
0 \\
0 \\
0
\end{array}\right] \\
\operatorname{Var}\left[\begin{array}{l}
y \\
a \\
c \\
e
\end{array}\right]=\left[\begin{array}{ccccc}
V & Z A \sigma_{a}^{2} & Z D \sigma_{d}^{2} & W I \sigma_{c}^{2} & I \sigma_{c}^{2} \\
A \sigma_{a}^{2} Z^{\prime} & A \sigma_{a}^{2} & 0 & 0 & 0 \\
D \sigma_{d}^{2} Z^{\prime} & 0 & D \sigma_{d}^{2} & 0 & 0 \\
I \sigma_{c}^{2} \mathrm{~W}^{\prime} & 0 & 0 & I \sigma_{c}^{2} & 0 \\
I \sigma_{e}^{2} & 0 & 0 & 0 & I \sigma_{e}^{2}
\end{array}\right]
\end{gathered}
$$

where

$$
V=Z A \sigma_{a}^{2} Z^{\prime}+Z D \sigma_{d}^{2} Z^{\prime}+W I \sigma_{c}^{2} W^{\prime}+I \sigma_{e}^{2}
$$

The mixed model equations are given through:

$$
\begin{gathered}
{\left[\begin{array}{cccc}
X^{\prime} X & X^{\prime} Z & X^{\prime} Z & X^{\prime} W \\
Z^{\prime} X & Z^{\prime} Z+A^{-1} \lambda_{1} & Z^{\prime} Z & Z^{\prime} W \\
Z^{\prime} X & Z^{\prime} Z & Z^{\prime} Z+D^{-1} \lambda_{2} & Z^{\prime} W \\
W^{\prime} Z & W^{\prime} Z & W^{\prime} Z & W^{\prime} W+I \lambda_{3}
\end{array}\right]\left[\begin{array}{l}
\hat{b} \\
\hat{a} \\
\hat{d} \\
\hat{c}
\end{array}\right]=\left[\begin{array}{c}
X^{\prime} y \\
Z^{\prime} y \\
Z^{\prime} y \\
W^{\prime} y
\end{array}\right] \text { (Equation 4) }} \\
\lambda_{1}=\frac{\sigma_{c}^{2}}{\sigma_{a}^{2}}=\frac{1-h_{a}^{2}-c^{2}}{h^{2}} ; \lambda_{1}=\frac{\sigma_{c}^{2}}{\sigma_{a}^{2}}=\frac{1-h_{a}^{2}-c^{2}}{h^{2}} ; \lambda_{3}=\frac{\sigma_{e}^{2}}{\sigma_{c}^{2}}=\frac{1-h_{a}^{2}-c^{2}}{c^{2}} \text { (Equation 5) }
\end{gathered}
$$

Genetics and Molecular Research 16 (2): gmr16029301 
$\sigma_{d}^{2}$ and $h_{a}^{2}$ : dominance genetic variance and individual heritability in the broad sense, respectively; D: matrix of dominance genetic correlation between the assessed individuals.

The iterative estimators of the REML variance components found through the expectation-maximization algorithm are:

$$
\widehat{\sigma}_{e}^{2}=\left[y^{\prime} y-\widehat{b}^{\prime} X^{\prime} y-\hat{a}{ }^{\prime} \mathrm{Z} y-\hat{\mathrm{d}} \mathrm{Z}^{\prime} \mathrm{y}-\hat{\mathrm{c}} W^{\prime} y\right] /[N-r(x)] \text { (Equation 6) }
$$

$\hat{\sigma}_{\theta}^{2}:$ residual variance

$$
\widehat{\sigma}_{c}^{2}=\left[\widehat{c}^{\prime} c+\widehat{\sigma}_{c}^{2} t r C^{44}\right] / s
$$

- 2

$\widehat{\sigma}_{c}=$ variance between plot

$$
\widehat{\sigma}_{a}^{2}=\left[\widehat{a}^{\prime} A^{-1} \hat{a}+\widehat{\sigma}_{c}^{2} \operatorname{tr}\left(A^{-1} C^{22}\right)\right] / q
$$

$\hat{\sigma}_{a}^{2}$ : additive genetic variance

$$
\widehat{\sigma}_{d}^{2}=\left[\widehat{d}^{\prime} D^{-1} \widehat{d}+\widehat{\sigma}_{e}^{2} \operatorname{tr}\left(D^{-1} C^{33}\right] / q\right.
$$

- 2

$\hat{\sigma}_{d}=$ dominance genetic variance

The families were classified according to their genotypic value. The individual ranking was based on the predicted genotypic mean $(\mu+\mathrm{g})$. As the elephant grass can vegetatively propagate, the genotype is integrally inherited. Thus, 38 superior progenies were ranked to produce biomass, which is the most important trait investigated in the current study.

\section{RESULTS AND DISCUSSION}

All the studied traits showed significant differences between genotypes (Table 2), indicating genetic variability among the populations. It was possible to successfully select promising genotypes and, therefore, obtain genetic gains in these populations. The only exception was found in the trait "dry biomass rate", which indicated that the genotypes showed similar performance in this trait.

It is worth knowing the origin of the genetic effects of the studied variables because such knowledge allows directing the strategies to be used in breeding programs. Overall, the genetic variation was explained by both the additive genetic effects and the dominance genetic effects (Table 3). However, there was a prevalence of dominance variance, which enabled heterosis capitalization. According to Cruz et al. (2012), the prevalence of dominanceassociated variance is desirable in breeding programs aimed at exploring the vigor found in hybrid combinations. Therefore, the significant heterosis manifestation is beneficial to the 
elephant grass, because it allows cloning the best individuals, as well as capitalizing both the dominance and the additive effects.

\begin{tabular}{|c|c|c|c|c|c|}
\hline \multirow[t]{3}{*}{ Character } & & \multicolumn{4}{|c|}{ Effect } \\
\hline & & \multicolumn{2}{|c|}{ Genotype } & \multicolumn{2}{|c|}{ Complet model } \\
\hline & & Cut 1 & Cut 2 & Cut 1 & Cut 2 \\
\hline \multirow[t]{2}{*}{ NT } & Deviance & 2625.87 & 1802.24 & \multirow[t]{2}{*}{2603.31} & \multirow[t]{2}{*}{1797.61} \\
\hline & LTR & $22.56^{* *}$ & $4.63^{*}$ & & \\
\hline \multirow[t]{2}{*}{$\mathrm{PH}$} & Deviance & -871.28 & -595.71 & \multirow{2}{*}{-883.52} & \multirow{2}{*}{-610.73} \\
\hline & LTR & $12.24^{* *}$ & $15.02^{* * *}$ & & \\
\hline \multirow{2}{*}{ CD } & Deviance & 1486.69 & 816.45 & \multirow[t]{2}{*}{1468.49} & \multirow[t]{2}{*}{812.53} \\
\hline & LTR & $18.20^{* *}$ & $3.92^{*}$ & & \\
\hline \multirow[t]{2}{*}{ FBIOM } & Deviance & 2278.57 & 1555.16 & \multirow{2}{*}{2269.00} & \multirow[t]{2}{*}{1546.86} \\
\hline & LTR & $9.57^{* *}$ & $8.30^{* *}$ & & \\
\hline \multirow[t]{2}{*}{ DBIOM } & Deviance & 1113.24 & 912.86 & \multirow{2}{*}{1103.12} & \multirow[t]{2}{*}{904.48} \\
\hline & LTR & $10.12^{* *}$ & $8.38^{* * *}$ & & \\
\hline \multirow[t]{2}{*}{ DBR } & Deviance & 1929.16 & 1406.29 & \multirow[t]{2}{*}{1927.34} & \multirow[t]{2}{*}{1405.01} \\
\hline & LTR & $1.82^{\mathrm{ns}}$ & $1.28^{\mathrm{ns}}$ & & \\
\hline
\end{tabular}

ns,***Non-significant and significant at 1 and $5 \%$ probability levels, respectively, according to the chi-square test with 1 degree of freedom. LRT: likelihood ratio test.

Table 3. Estimates of variance components and genetic parameters concerning the number of tillers (NT), plant height (PH), culm diameter (CD), fresh biomass (FBIOM), dry biomass (DBIO), and dry biomass rate (DBR) of parents and full-sib families of elephant grass.

\begin{tabular}{|c|c|c|c|c|c|c|c|c|c|c|c|c|}
\hline \multirow[t]{2}{*}{ Parameter } & \multicolumn{2}{|c|}{ NT } & \multicolumn{2}{|c|}{$\mathrm{PH}$} & \multicolumn{2}{|c|}{$\mathrm{CD}$} & \multicolumn{2}{|c|}{ FBIOM } & \multicolumn{2}{|c|}{ DBIOM } & \multicolumn{2}{|c|}{ DBR } \\
\hline & Cut 1 & Cut 2 & Cut 1 & Cut 2 & Cut 1 & Cut 2 & Cut 1 & Cut 2 & Cut 1 & Cut 2 & Cut 1 & Cut 2 \\
\hline$\hat{\sigma}_{a}^{2}$ & 0.295 & 6.317 & 0.0002 & 0.0001 & 0.011 & 0.008 & 0.048 & 0.073 & 0.006 & 0.010 & 0.010 & 0.374 \\
\hline$\hat{\sigma}_{\text {parc }}^{2}$ & 4.287 & 13.403 & 0.025 & 0.005 & 0.787 & 0.615 & 2.758 & 8.740 & 0.310 & 1.252 & 0.349 & 0.224 \\
\hline$\hat{\sigma}_{\text {fam }}^{2}$ & 12.421 & 1.559 & 0.026 & 0.015 & 1.552 & 0.367 & 3.464 & 7.197 & 0.415 & 1.051 & 0.380 & 0.013 \\
\hline$\hat{\sigma}_{\theta}^{2}$ & 36.955 & 32.810 & 0.055 & 0.058 & 4.487 & 2.613 & 20.314 & 16.830 & 2.376 & 3.080 & 11.875 & 15.199 \\
\hline$\hat{\sigma}_{f}^{2}$ & 53.959 & 54.089 & 0.106 & 0.079 & 6.838 & 3.604 & 26.584 & 32.840 & 3.107 & 5.393 & 12.614 & 15.810 \\
\hline$\widehat{h}_{a}^{2}$ & 0.005 & 0.117 & 0.002 & 0.001 & 0.002 & 0.002 & 0.002 & 0.002 & 0.002 & 0.002 & 0.001 & 0.024 \\
\hline$\widehat{h}_{g}^{2}$ & 0.926 & 0.232 & 0.967 & 0.784 & 0.910 & 0.410 & 0.523 & 0.879 & 0.537 & 0.782 & 0.121 & 0.027 \\
\hline$\hat{r}_{\hat{g} g}$ & 0.962 & 0.482 & 0.983 & 0.885 & 0.954 & 0.640 & 0.723 & 0.937 & 0.732 & 0.884 & 0.348 & 0.164 \\
\hline$\hat{c}_{\text {pare }}^{2}$ & 0.079 & 0.248 & 0.240 & 0.062 & 0.115 & 0.171 & 0.104 & 0.266 & 0.100 & 0.232 & 0.028 & 0.014 \\
\hline$\hat{c}_{\text {fam }}^{2}$ & 0.230 & 0.029 & 0.241 & 0.196 & 0.227 & 0.102 & 0.130 & 0.219 & 0.134 & 0.195 & 0.030 & 0.001 \\
\hline$\mu$ & 20.20 & 22.34 & 3.66 & 2.80 & 16.03 & 15.89 & 13.28 & 13.33 & 4.25 & 5.17 & 31.97 & 38.73 \\
\hline
\end{tabular}
$\hat{\sigma}_{a}^{2}$ : additive genetic variance; $\hat{\sigma}_{\text {parc }}^{2}$ : environmental variance between plots; $\hat{\sigma}_{\text {fam }}^{2}$ : dominance genetic variance; $\hat{\sigma}_{\theta}^{2}$ : residual variance; $\hat{\sigma}_{f}^{2}$ : individual phenotypic variance; $\widehat{h}_{a}^{2}$ : individual heritability in the narrow sense; $\widehat{h}_{g}^{2}$ : individual heritability in the broad sense; $\hat{r}_{\hat{g} g}$ : selective accuracy; $\hat{c}_{\text {parc }}^{2}$ : coefficient of determination of the plot effects; $\hat{C}_{f a m}^{2}$ : coefficient of determination of the specific combination ability effects.

The heritability in the narrow sense is useful in breeding programs, because it quantifies the additive proportion of the genetic variance to be transferred to the next generation. However, in the case of vegetatively propagated plants, such as the elephant

Genetics and Molecular Research 16 (2): gmr16029301 
grass, whose genotype is fully inherited by the progenies, the heritability in the broad sense is most important, because the genetic variability is released, at once, during the crossing stage. Subsequently, the genotype is fixed, and there is no segregation in the next stages (Zhou and Joshi, 2012).

The highest estimation value concerning heritability in the broad sense was observed in the trait "plant height" in Cut 1 (Table 3), and it indicated that $96.7 \%$ of the variance was of genetic nature. On the other hand, the lowest estimated value for such parameter was observed in the trait "dry biomass rate" $(0.121)$, and it indicated high environmental variance.

Most of the studied traits showed significant genetic control, which could be seen, for instance, in the high selective accuracy magnitude of plant height estimates (98.3\%). This parameter concerns the selection accuracy and reflects the correlation between the predicted and the true genetic values of individuals (Resende, 2007), thus demonstrating the reliability of the values predicted to the population. The coefficient of determination concerning the plot effects quantifies the environmental effects between plots within the blocks. This parameter showed low values, and it indicated reduced environmental variability between plots. Resende (2002) has reported that good experiments using perennial plants presented $\hat{c}_{\text {parc }}^{2}$ values close to $10 \%$ of all the phenotypic variation within the blocks, which was caused by the variation between plots.

The selection of families based on the genotypic value of the crossing $(\mathrm{gVc})$ allowed selecting a larger number of promising individuals presenting the traits of interest. Thus, families presenting $\mathrm{gVc}$ above the mean were selected for each trait. The variable "number of tillers" gathered the largest number of families that met such condition, namely: Cameroon $\mathrm{x}$ Cuba-11; Cameroon x Guaçu/I.Z.2; Capim Cana D’África x Guaçu

I.Z.2; CPAC x Cuba-115; Capim Cana D’África x Cuba-115; IAC-Campinas x IJ 7139; and IAC-Campinas x Guaçu/I.Z.2; when both assessment cuts were taken into consideration (Table 4). The number of tillers is relevant in studies that aim to increase the dry biomass production because there is a correlation between high genetic nature and dry matter production (Cunha et al., 2011). Only a single family, derived from the crossing between Cameroon x Guaçu/I.Z.2, showed plant height above the mean when both assessment cuts were taken into consideration.

Among the investigated traits, the dry biomass production was the most relevant one when it came to bioenergy production increase. Therefore, it is worth making efforts to select the largest number of superior families to increase the possibility of identifying superior individuals to produce biomass. Capim Cana D'África x Guaçu I.Z.2, Cameroon x Cuba-11, CPAC x Cuba-115, Cameroon x Guaçu/I.Z.2, and IAC-Campinas x IJ 7139 were the best families when both assessment cuts were taken into consideration (Table 4).

It is worth emphasizing that these families kept superior performance regardless of the assessment cut. According to Cunha et al. (2011), such situation is favorable, because it is known that the elephant grass, like all forage plants, is subject to seasonality. Thus, it presents productivity variation in certain periods of the year. Since it is possible to perform two cuts per year, it is preferable to select genotypes whose dry biomass production is as stable as possible.

It is noteworthy that the families derived from the crossing between Capim Cana D'África and Guaçu/I.Z.2 showed the best performance in variables such as plant height, culm diameter, fresh biomass production, dry biomass production, and dry biomass rate. As for the improvement of quantitative traits, it is hardly possible aggregating several traits of interest

Genetics and Molecular Research 16 (2): gmr16029301 
Table 4. Estimate of the genotypic values of the crossing $(\mathrm{gVc})$ for traits such as the number of tillers (NT), plant height $(\mathrm{PH})$, culm diameter (CD), fresh biomass (FBIOM), dry biomass (DBIOM), and dry biomass rate (DBR) of 15 full-sib families of elephant grass.

\begin{tabular}{|c|c|c|c|c|c|c|c|c|c|c|c|c|}
\hline \multirow[t]{2}{*}{ Family/Crossing } & \multicolumn{2}{|c|}{ NT } & \multicolumn{2}{|c|}{$\mathrm{PH}$} & \multicolumn{2}{|c|}{$\mathrm{CD}$} & \multicolumn{2}{|c|}{ FBIOM } & \multicolumn{2}{|c|}{ DBIOM } & \multicolumn{2}{|c|}{ DBR } \\
\hline & Cut 1 & Cut 2 & Cut 1 & Cut 2 & Cut 1 & Cut 2 & Cut 1 & Cut 2 & Cut 1 & Cut 2 & Cut 1 & Cut 2 \\
\hline $11(1 \times 5)$ & 19.94 & 22.06 & 3.54 & 2.74 & 15.43 & 15.31 & 11.57 & 11.80 & 3.71 & 4.51 & 32.20 & 38.57 \\
\hline $12(1 \times 6)$ & 19.26 & 20.63 & 3.64 & 2.66 & 15.92 & 15.72 & 11.71 & 10.23 & 3.81 & 3.99 & 32.48 & 38.72 \\
\hline $13(1 \times 7)$ & 21.34 & 20.98 & 3.48 & 2.64 & 15.00 & 15.73 & 12.49 & 11.07 & 3.90 & 4.34 & 31.49 & 38.95 \\
\hline $14(2 \times 6)$ & 18.45 & 20.75 & 3.58 & 2.66 & 15.35 & 15.40 & 11.45 & 11.23 & 3.58 & 4.43 & 31.56 & 38.88 \\
\hline $15(2 \times 7)$ & 20.27 & 21.47 & 3.64 & 2.74 & 15.79 & 15.58 & 12.81 & 11.39 & 4.14 & 4.55 & 31.99 & 39.10 \\
\hline $16(2 \times 8)$ & 17.11 & 20.65 & 3.52 & 2.70 & 14.57 & 15.59 & 10.30 & 10.67 & 3.20 & 4.25 & 31.84 & 39.13 \\
\hline $17(3 \times 7)$ & 24.24 & 22.55 & 3.61 & 2.72 & 16.09 & 15.74 & 14.35 & 13.28 & 4.44 & 5.43 & 31.34 & 38.99 \\
\hline $18(3 \times 8)$ & 19.65 & 21.39 & 3.50 & 2.81 & 15.29 & 16.10 & 11.85 & 11.95 & 3.69 & 4.67 & 31.52 & 39.00 \\
\hline $19(3 \times 9)$ & 20.70 & 22.83 & 3.61 & 2.71 & 15.11 & 15.66 & 12.03 & 11.24 & 3.92 & 4.35 & 32.26 & 38.53 \\
\hline $20(4 \times 8)$ & 21.65 & 20.38 & 3.56 & 2.64 & 14.84 & 15.17 & 12.70 & 9.75 & 4.06 & 3.83 & 32.00 & 39.05 \\
\hline $21(4 \times 9)$ & 26.28 & 23.92 & 3.64 & 2.92 & 15.83 & 16.39 & 16.68 & 16.67 & 5.57 & 6.45 & 32.61 & 38.58 \\
\hline $22(4 \times 10)$ & 20.95 & 23.06 & 3.36 & 2.71 & 14.17 & 15.74 & 11.43 & 11.05 & 3.56 & 4.18 & 31.50 & 38.50 \\
\hline $23(5 \times 9)$ & 24.56 & 24.42 & 3.74 & 2.84 & 15.36 & 16.27 & 13.99 & 14.52 & 4.51 & 5.57 & 32.04 & 38.35 \\
\hline $24(5 \times 10)$ & 27.24 & 24.88 & 3.49 & 2.73 & 15.61 & 15.40 & 14.90 & 13.24 & 4.65 & 4.95 & 31.38 & 38.25 \\
\hline $25(6 \times 10)$ & 23.87 & 23.77 & 3.63 & 2.74 & 15.21 & 16.14 & 14.06 & 14.13 & 4.52 & 5.42 & 31.96 & 38.41 \\
\hline
\end{tabular}

in the same genotype. Thus, it is necessary to select the largest number of individuals in the family to obtain the largest number of potential genotypes to be assessed in the subsequent stages of elephant grass-breeding programs geared to biomass production.

The family selection increases the likelihood of identifying superior individuals because such selection comprises both the best families and the superior individuals within each family (Santos et al., 2008; Cruz et al., 2012). The veracity of this information in the current study is confirmed in Table 4 since the best family assembled the largest number of superior individuals. Of the 38 progenies ranked in Cuts 1 and 2, 36.84 and 23.68\%, respectively, belonged to the best family (21), which derived from the crossing between Capim Cana D'África and Guaçu I.Z.2. The other families that also assembled a significant number of individuals were: Cameroon x Guaçu/I.Z.2, Cameroon x Cuba-115, CPAC x Cuba-115, and IAC-Campinas x IJ 7139.

The individual 5 belonging to the family Capim Cana D'África x Guaçu I.Z.2, planted in blocks 1 and 2, showed the best dry biomass production in cuts 1 and 2, respectively (Table 5). It is noteworthy that all the selected individuals showed predicted genotypic mean higher than the overall mean. The families showing $\mathrm{gVc}$ lower than the overall mean should be discarded since they are less likely to generate superior progenies.

There was a prevalence of dominance genetic effects in the control of all traits. The families Capim Cana D'África x Guaçu/I.Z.2, Cameroon x Cuba-115, CPAC x Cuba-115, Cameroon x Guaçu/I.Z.2, and IAC-Campinas x IJ 7139 showed the highest dry biomass production. The family Capim Cana D’África x Guaçu/I.Z.2 assembled the largest number of potential individuals when it came to variables such as plant height, culm diameter, fresh biomass production, dry biomass production, and dry biomass rate. The individual 5 belonging to the family Cana D'África x Guaçu/I.Z.2, planted in blocks 1 and 2, showed the highest dry biomass production.

The REML/BLUP family-selection strategy efficiently identified the families showing high genotypic values, as well as the families with significant probability to hold potential elephant grass clones for bioenergy production means.

Genetics and Molecular Research 16 (2): gmr16029301 
Table 5. Selection of superior progenies derived from full-sib families of elephant grass to produce dry biomass (kg/plant).

\begin{tabular}{|c|c|c|c|c|c|c|c|c|c|c|c|c|c|c|}
\hline \multirow[t]{2}{*}{ Order } & \multicolumn{2}{|c|}{ Block } & \multicolumn{2}{|c|}{ Family } & \multicolumn{2}{|c|}{ Plant } & \multicolumn{2}{|c|}{ f } & \multicolumn{2}{|c|}{$\mu+\mathrm{a}$} & \multicolumn{2}{|c|}{$\mu+d$} & \multicolumn{2}{|c|}{$\mu+g$} \\
\hline & $\mathrm{C} 1$ & $\mathrm{C} 2$ & $\mathrm{C} 1$ & $\mathrm{C} 2$ & $\mathrm{C} 1$ & $\mathrm{C} 2$ & $\mathrm{C} 1$ & $\mathrm{C} 2$ & $\mathrm{C} 1$ & $\mathrm{C} 2$ & $\mathrm{C} 1$ & $\mathrm{C} 2$ & $\mathrm{C} 1$ & $\mathrm{C} 2$ \\
\hline 1 & 1 & 2 & 21 & 17 & 5 & 5 & 10.65 & 16.72 & 4.27 & 5.19 & 7.85 & 14.28 & 7.86 & 14.29 \\
\hline 2 & 3 & 2 & 21 & 21 & 7 & 2 & 9.95 & 11.68 & 4.27 & 5.19 & 7.65 & 11.24 & 7.66 & 11.25 \\
\hline 3 & 2 & 3 & 21 & 25 & 2 & 5 & 9.10 & 9.82 & 4.27 & 5.18 & 7.48 & 9.98 & 7.50 & 9.98 \\
\hline 4 & 3 & 1 & 21 & 21 & 3 & 1 & 9.40 & 10.30 & 4.27 & 5.19 & 7.36 & 9.91 & 7.37 & 9.93 \\
\hline 5 & 1 & 2 & 24 & 25 & 5 & 3 & 9.42 & 10.68 & 4.26 & 5.18 & 6.97 & 9.87 & 6.98 & 9.87 \\
\hline 6 & 2 & 3 & 13 & 24 & 4 & 3 & 9.49 & 8.90 & 4.26 & 5.18 & 6.73 & 9.54 & 6.74 & 9.55 \\
\hline 7 & 1 & 1 & 21 & 23 & 1 & 2 & 8.38 & 10.33 & 4.27 & 5.19 & 6.66 & 9.09 & 6.67 & 9.11 \\
\hline 8 & 2 & 2 & 17 & 17 & 5 & 4 & 8.68 & 11.12 & 4.26 & 5.18 & 6.58 & 8.55 & 6.59 & 8.56 \\
\hline 9 & 3 & 3 & 23 & 23 & 5 & 4 & 8.58 & 8.43 & 4.27 & 5.19 & 6.50 & 8.47 & 6.52 & 8.48 \\
\hline 10 & 3 & 1 & 24 & 25 & 3 & 2 & 8.00 & 7.70 & 4.26 & 5.18 & 6.47 & 8.33 & 6.48 & 8.34 \\
\hline 11 & 2 & 1 & 21 & 21 & 5 & 3 & 6.94 & 8.67 & 4.27 & 5.18 & 6.35 & 8.25 & 6.36 & 8.26 \\
\hline 12 & 3 & 2 & 21 & 21 & 5 & 1 & 7.28 & 8.64 & 4.27 & 5.18 & 6.25 & 8.13 & 6.26 & 8.14 \\
\hline 13 & 3 & 3 & 21 & 21 & 4 & 4 & 7.27 & 8.58 & 4.27 & 5.18 & 6.24 & 8.09 & 6.25 & 8.10 \\
\hline 14 & 2 & 2 & 25 & 25 & 8 & 5 & 8.09 & 8.56 & 4.26 & 5.17 & 6.23 & 7.70 & 6.24 & 7.70 \\
\hline 15 & 3 & 3 & 24 & 18 & 1 & 5 & 7.31 & 7.92 & 4.26 & 5.17 & 6.11 & 7.68 & 6.12 & 7.68 \\
\hline 16 & 1 & 2 & 21 & 19 & 3 & 5 & 7.32 & 7.69 & 4.26 & 5.18 & 6.10 & 7.66 & 6.11 & 7.67 \\
\hline 17 & 3 & 1 & 25 & 22 & 6 & 4 & 7.27 & 7.78 & 4.26 & 5.18 & 5.98 & 7.32 & 5.98 & 7.33 \\
\hline 18 & 2 & 2 & 25 & 15 & 3 & 5 & 7.36 & 8.05 & 4.26 & 5.18 & 5.85 & 7.32 & 5.86 & 7.33 \\
\hline 19 & 1 & 3 & 25 & 21 & 7 & 1 & 6.95 & 7.67 & 4.26 & 5.18 & 5.82 & 7.16 & 5.83 & 7.17 \\
\hline 20 & 2 & 3 & 23 & 15 & 8 & 4 & 6.71 & 6.64 & 4.27 & 5.18 & 5.79 & 7.07 & 5.80 & 7.07 \\
\hline 21 & 2 & 3 & 21 & 23 & 3 & 5 & 5.84 & 6.98 & 4.26 & 5.18 & 5.78 & 6.99 & 5.79 & 7.00 \\
\hline 22 & 1 & 1 & 21 & 17 & 6 & 3 & 6.64 & 6.59 & 4.26 & 5.17 & 5.75 & 6.98 & 5.76 & 6.98 \\
\hline 23 & 1 & 3 & 23 & 21 & 5 & 3 & 7.00 & 7.32 & 4.27 & 5.18 & 5.70 & 6.80 & 5.71 & 6.81 \\
\hline 24 & 2 & 1 & 15 & 23 & 4 & 1 & 7.51 & 8.03 & 4.25 & 5.18 & 5.69 & 6.74 & 5.68 & 6.75 \\
\hline 25 & 2 & 2 & 24 & 24 & 5 & 4 & 6.66 & 6.94 & 4.26 & 5.18 & 5.64 & 6.50 & 5.65 & 6.50 \\
\hline 26 & 3 & 1 & 23 & 24 & 6 & 2 & 6.92 & 6.25 & 4.27 & 5.18 & 5.64 & 6.49 & 5.65 & 6.49 \\
\hline 27 & 2 & 1 & 24 & 15 & 3 & 1 & 6.60 & 5.22 & 4.26 & 5.17 & 5.61 & 6.42 & 5.62 & 6.43 \\
\hline 28 & 3 & 2 & 23 & 24 & 8 & 1 & 6.78 & 6.85 & 4.27 & 5.18 & 5.56 & 6.41 & 5.57 & 6.41 \\
\hline 29 & 1 & 1 & 17 & 14 & 3 & 1 & 6.10 & 5.31 & 4.25 & 5.17 & 5.41 & 6.39 & 5.41 & 6.38 \\
\hline 30 & 1 & 3 & 17 & 11 & 6 & 4 & 6.01 & 7.32 & 4.25 & 5.18 & 5.36 & 6.34 & 5.36 & 6.34 \\
\hline 31 & 2 & 1 & 17 & 21 & 6 & 5 & 6.25 & 6.80 & 4.25 & 5.18 & 5.31 & 6.33 & 5.31 & 6.34 \\
\hline 32 & 1 & 3 & 21 & 21 & 7 & 5 & 5.79 & 6.85 & 4.26 & 5.18 & 5.30 & 6.32 & 5.31 & 6.33 \\
\hline 33 & 1 & 2 & 15 & 15 & 1 & 1 & 5.66 & 7.06 & 4.25 & 5.17 & 5.30 & 6.31 & 5.30 & 6.31 \\
\hline 34 & 1 & 2 & 21 & 16 & 4 & 4 & 5.75 & 6.43 & 4.26 & 5.17 & 5.28 & 6.27 & 5.29 & 6.27 \\
\hline 35 & 3 & 1 & 15 & 17 & 2 & 5 & 6.48 & 5.89 & 4.25 & 5.17 & 5.28 & 6.26 & 5.28 & 6.26 \\
\hline 36 & 2 & 2 & 21 & 13 & 1 & 4 & 4.86 & 6.88 & 4.26 & 5.18 & 5.26 & 6.24 & 5.27 & 6.24 \\
\hline 37 & 1 & 1 & 15 & 18 & 3 & 4 & 5.54 & 4.86 & 4.25 & 5.17 & 5.24 & 6.12 & 5.24 & 6.11 \\
\hline 38 & 1 & 1 & 24 & 24 & 4 & 5 & 5.95 & 5.88 & 4.26 & 5.18 & 5.16 & 6.11 & 5.16 & 6.11 \\
\hline
\end{tabular}

C1: Cut 1; C2: Cut 2.

\section{ACKNOWLEDGMENTS}

The authors are grateful to Coordenação de Aperfeiçoamento de Pessoal de Nível Superior (CAPES) for the financial support.

\section{REFERENCES}

Bordonal RO, Lal R, Aguiar DA, Figueiredo EB, et al. (2015). Greenhouse gas balance from cultivation and direct land use change, of recently established sugarcane (Saccharum officinarum) plantation in south-central Brazil. Renew. Sustain. Energy Rev. 52: 547-556 https://doi.org/10.1016/j.rser.2015.07.137.

Braz TGDS, Fonseca DMD, Jank L, Resende MDVD, et al. (2013). Genetic parameters of agronomic characters in Panicum maximum hybrids. Rev. Bras. Zootec. 42: 231-237 https://doi.org/10.1590/S1516-35982013000400001.

Carias CMDOM, Gravina GA, Ferrão MAG, Fonseca AFA, et al. (2016). Predição de ganhos genéticos via modelos mistos em Progênies de café conilon. Coffee Sci. 11: 39-45.

Cruz CD, Regazzi AJ and Carneiro PCS (2012). Métodos biométricos aplicados ao melhoramento genético. Imprensa Universitária, UFV, Viçosa.

Genetics and Molecular Research 16 (2): gmr16029301 
Cunha MVD, Lira MDA, Santos MVFD, Freitas EVD, et al. (2011). Association between the morphological and productive characteristics in the selection of elephant grass clones. Rev. Bras. Zootec. 40: 482-488 https://doi.org/10.1590/ S1516-35982011000300004.

Daher RF, Souza LB, Gravina GA, Machado JC, et al. (2014). Use of elephant grass for energy production in Campos dos Goytacazes-RJ, Brazil. Genet. Mol. Res. 13: 10898-10908 https://doi.org/10.4238/2014.December.19.11.

Eufrade Junior HJ, Melo RX, Sartori MMP, Guerra SPS, et al. (2016). Sustainable use of eucalypt biomass grown on short rotation coppice for bioenergy. Biomass Bioenergy 90: 15-21 https://doi.org/10.1016/j.biombioe.2016.03.037.

Figueiredo UJ, Nunes JAR and Valle CBD (2012). Estimation of genetic parameters and selection of Brachiaria humidicola progenies using a selection index. Crop Breed. Appl. Biotechnol. 12: 237-244 https://doi.org/10.1590/ $\underline{\text { S1984-70332012000400002. }}$.

Ghosh SK (2016). Biomass \& Bio-waste Supply Chain Sustainability for Bio-energy and Bio-fuel Production. Procedia Environ. Sci. 31: 31-39 https://doi.org/10.1016/j.proenv.2016.02.005.

Kempthorne O and Curnow RN (1961). The partial diallel cross. Biometrics 17: 229-250. https://doi.org/10.2307/2527989

Köpen W (1948). Climatologia. Buenos Aires: Gráfica Panamericana.

Lucius ASF, Oliveira RA, Daros E, Zambon JLC, et al. (2014). Performance of sugarcane families at different stages in the genetic improvement by REML/BLUP. Semin. Cienc. Agrar. 35: 101-111. https://doi.org/10.5433/1679$\underline{0359.2014 \mathrm{v} 35 \mathrm{n} 1 \mathrm{p} 101}$

Mazzarella VNG, Seguchi HJM and Ferreira PH (2015). Balanço energético do capim elefante x eucalipto. Eng. Sci. 3: 1.

Mendonça JC, Sousa EF, Bernardo S, Sugawara MT, et al. (2007). Determinação do coeficiente cultural (Kc) do feijoeiro (Phaseolus vulgaris L.) em Campos dos Goytacazes, RJ. Rev. Bras. Eng. Agric. Ambient. 11: 471-475 https://doi. org/10.1590/S1415-43662007000500004.

Menezes BRS, Daher RF, Gravina AG, Gottardo RD, et al. (2016). Comportamento per se de híbridos de capim-elefante para fins energéticos. Comun. Sci. 7: 73-85 https://doi.org/10.14295/cs.v7i1.946.

Miranda AC, Moraes MLT, Silva PHM and Sebbenn AM (2015). Genetic gain in the selection by multi-effects index in open-pollinated progenies of Eucalyptus grandis Hill ex Maiden. Sci. For. 43: 203-209.

Oliveira RA, Daros E, Bespalhok Filho JC, Zambon JLC, et al. (2008). Seleção de famílias de cana-de-açúcar via modelos mistos. Sci. Agrar. 9: 269-274 https://doi.org/10.5380/rsa.v9i3.11564.

Ong HC, Silitonga AS, Masjuki HH, Mahlia TMI, at al. (2013). Production and comparative fuel properties of biodiesel from non-edible oils: Jatropha curcas, Sterculia foetida and Ceiba pentandra. Energy Convers. Manage. 73: 245-255 https://doi.org/10.1016/j.enconman.2013.04.011.

Pedrozo CÂ, Benites FRG, Barbosa MHP, Resende MDV, et al. (2009). Eficiência de índices de seleção utilizando a metodologia REML/BLUP no melhoramento da cana-de-açúcar. Sci. Agrar. 10: 31-36. https://doi.org/10.5380/rsa. v10i1.11711

Resende MD (2002). Genética biométrica e estatística no melhoramento de plantas perenes. Brasília: Embrapa Informação Tecnológica. Colombo: Embrapa Florestas.

Resende MDV (2007) SELEGEN-REML/BLUP: sistema estatístico e seleção genética computadorizada via modelos lineares mistos. Colombo: Embrapa Florestas.

Rocha AS, Daher RF, Gravina GA, Pereira VA, et al. (2015). Comparison of stability methods in elephant-grass genotypes for energy purposes. Afr. J. Agric. Res. 10: 4283-4294 https://doi.org/10.5897/AJAR2015.10218.

Rodrigues WP, Vieira HD, Barbosa DH, Souza Filho GR, et al. (2013). Adaptability and genotypic stability of Coffea arabica genotypes based on REML/BLUP analysis in Rio de Janeiro State, Brazil. Genet. Mol. Res. 12: 2391-2399 https://doi.org/10.4238/2013.July.15.2.

Rosado AM, Rosado TB, Alves AA, Laviola BG, et al. (2012). Seleção simultânea de clones de eucalipto de acordo com produtividade, estabilidade e adaptabilidade. Pesqui. Agropecu. Bras. 47: 964-971 https://doi.org/10.1590/S0100204X2012000700013.

Salazar-Zeledón E, Moya R and Valaert J (2015). Biomass and Bioenergy Production of Arundo donax L., Pennisetum purpureum Schum and Pennisetum purpureum Schumack. $\times$ Pennisetum glaucum L. in Short Rotation Cropping System in Costa Rica. J. Biobased Mater. Bioenergy 9: 572-579 https://doi.org/10.1166/jbmb.2015.1562.

Santos CEM, Pissioni LLM, Morgado MADO, Cruz CD, et al. (2008). Estratégias de seleção em progênies de maracujazeiroamarelo quanto ao vigor e incidência de verrugose. Rev. Bras. Frutic. 30: 444-449 https://doi.org/10.1590/S010029452008000200030.

Silva AL, Tardin FD, Rotta GW, Baldoni AB, et al. (2016). Characterization of biomass sorghum cultivars aiming to generate energy for the north region of Mato Grosso, Brazil. Nativa (Sinop) 4: 175-178 https://doi.org/10.14583/23187670.v04n03a11.

Szczerbowski D, Pitarelo AP, Zandoná Filho A and Ramos LP (2014). Sugarcane biomass for biorefineries: comparative

Genetics and Molecular Research 16 (2): gmr16029301 
composition of carbohydrate and non-carbohydrate components of bagasse and straw. Carbohydr. Polym. 114: 95$101 \mathrm{https://doi.org/10.1016/j.carbpol.2014.07.052.}$

Viana AP and Resende MDV (2014) Genética quantitativa no melhoramento de fruteiras. 1. Ed. Rio de Janeiro: Interciência. Zhou M and Joshi S (2012). Trends in broad sense heritability and implications for sugarcane breeding in South Africa. Sugar Tech 14: 40-46 https://doi.org/10.1007/s12355-011-0128-7.

Genetics and Molecular Research 16 (2): gmr16029301 